\title{
Prostaglandin Production by Human Gingival Fibroblasts Inhibited by Triclosan in the Presence of Cetylpyridinium Chloride
}

\author{
Young Joon Kim, ${ }^{*}$ Carlos Rossa Jr., ${ }^{\dagger}$ and Keith L. Kirkwood ${ }^{\ddagger}$
}

Background: The effect of triclosan plus the cationic detergent cetylpyridinium chloride (CPC) was evaluated for prostaglandin inhibition in human gingival fibroblasts. Since triclosan has previously been shown to inhibit proinflammatory cytokine induced prostaglandin $\mathrm{E}_{2}\left(\mathrm{PGE}_{2}\right)$ production, we wanted to determine if triclosan, in the presence of CPC, could enhance these effects.

Methods: Initial studies determined that both triclosan and CPC were cytotoxic to human gingival fibroblasts in concentrations exceeding $1.0 \mu \mathrm{g} / \mathrm{ml}$ for either agent longer than 24 hours in a tissue culture. Therefore, subsequent studies measuring prostaglandin biosynthesis and cyclooxygenase (COX)- 1 and COX-2 mRNA expression were performed in concentrations and times that did not significantly affect cell viability.

Results: PGE 2 biosynthesis was dose dependently inhibited by both triclosan and triclosan and CPC when challenged by tumor necrosis factor (TNF)- $\alpha$ or interleukin (IL)-1 $\beta$. At pharmacologically relevant concentrations, triclosan and CPC inhibited IL-1 $\beta$-induced $\mathrm{PGE}_{2}$ production to a greater extent than triclosan alone $(P=0.02)$. Moreover, enhanced COX-2 mRNA repression was observed with triclosan and CPC in comparison to triclosan alone in IL-1 $\beta$ and TNF- $\alpha$ stimulated cells. No effect on COX-1 gene expression was observed. Further analysis of cell signaling mechanisms of triclosan and $\mathrm{CPC}$ indicates that nuclear factor-kappa $\mathrm{B}(\mathrm{NF}-\kappa \mathrm{B})$ and not p38 mitogen-activated protein kinase (MAPK) signaling may be impaired in the presence of triclosan and CPC.

Conclusion: This study indicates that triclosan and CPC are more effective at inhibiting $\mathrm{PGE}_{2}$ at the level of COX-2 gene regulation, and this combination may offer a potentially better anti-inflammatory agent in the treatment of inflammatory lesions in the oral cavity. $J$ Periodontol 2005;76:1735-1742.

\section{KEY WORDS}

Cetylpyridinium chloride; COX-2; fibroblasts; $\mathrm{PGE}_{2}$; triclosan.

\footnotetext{
* Department of Periodontics and Dental Science Research Institute, Chonnam National University, Kwang-Ju, Korea.

$\dagger$ Department of Diagnosis and Surgery, School of Dentistry at Araraquara, State University of Sao Paulo (UNESP), Araraquara, SP, Brazil.

† Department of Periodontics and Oral Medicine, University of Michigan, Ann Arbor, MI.
}

$\mathrm{P}$ roinflammatory cytokines, such as interleukin (IL) $-1 \beta$ and tumor necrosis factor (TNF)- $\alpha$, produced by activated monocytes or macrophages mediate a multitude of inflammatory and wound repair responses. ${ }^{1,2}$ These cytokines are well-documented stimulators of bone resorption through induction of other osteoclastogenic cytokines, including IL-6 family members and the receptor activator of nuclear factor-kappa B ligand (RANKL) in osteoblasts. ${ }^{3,4}$ In addition, these cytokines mediate inflammation through stimulation of a wide variety of cytokines as well as stimulating prostaglandin production in oral tissues including gingival fibroblasts. ${ }^{5-7}$

Prostaglandins play an important role in inflammation associated with periodontitis. ${ }^{1,8}$ Prostaglandin $\mathrm{E}_{2}\left(\mathrm{PGE}_{2}\right)$ is found in higher levels in periodontally inflamed tissues and participates in alveolar bone resorption. ${ }^{9}$ The production of prostaglandins is regulated by the enzymes phospholipase $\mathrm{A}_{2}\left(\mathrm{PLA}_{2}\right)$ and cyclooxygenase (COX). These enzymes catalyze the liberation of arachidonic acid (AA) from membrane bound phospholipids whereas COX mediates the conversion of AA to prostaglandins. Two distinct genes encode the COX enzymes. The COX-1 gene is principally homeostatic in function as it possesses a typical GC-rich housekeeping promoter. In contrast, the COX-2 gene resembles an early response gene. It is 
strongly induced by mitogenic and proinflammatory mediators, superinduced by inhibitors of protein synthesis, and acutely regulated at the transcriptional and post-transcriptional levels. ${ }^{10}$

Triclosan (2,4,4' -trichloro-2' -hydroxydiphenyl ether) is a lipid soluble antimicrobial agent that has been included in the formulations of dentifrices, mouthrinses, and cosmetics. In addition to its antibacterial activity, other investigators have focused on the anti-inflammatory activity in oral soft tissue as well as skin in vivo. ${ }^{11-14}$ In vitro studies, primarily with gingival fibroblasts, have shown that triclosan can inhibit prostaglandin production induced by proinflammatory mediators, such as TNF- $\alpha$ and IL- $1 \beta .{ }^{15,16}$ Regulation of prostaglandin production by triclosan has been shown to occur at the level COX-2 gene expression. ${ }^{15}$

Cetylpyridinium chloride (CPC) is a surface-active quaternary ammonium disinfectant containing hydrophobic and hydrophilic residues. The bactericidal effects of this cationic agent have been associated with its ability to inactivate membrane-associated enzymes or by physical disorganization of the bacterial membrane itself. More recent studies have focused on the potential ability of CPC to function as an absorption enhancer of other drugs or peptides. ${ }^{17,18}$ The properties of this cationic compound to interact with cell surface-negative charges have been shown to increase the permeability of epithelial cells through intercellular and/or paracellular routes. ${ }^{18}$ Thus, it was hypothesized that triclosan in the presence of CPC may offer a greater anti-inflammatory effect compared to triclosan alone in a gingival fibroblast cell culture model system.

\section{MATERIALS AND METHODS}

\section{Tissue Culture}

Human gingival fibroblasts (HGF-1; ATCC CRL2014) were cultured in Dulbecco's modified Eagle's medium (DMEM), $\$$ supplemented with $10 \%$ fetal bovine serum,\| $100 \mathrm{U} / \mathrm{ml}$ penicillin, and $100 \mu \mathrm{g} / \mathrm{ml}$ streptomycin at $37^{\circ} \mathrm{C}$ in a humidified atmosphere of $5 \%$ $\mathrm{CO}_{2}$ in air. Experiments were conducted with cell passages 16 to 20 .

\section{Cytotoxicity Assays}

HGF-1 cells were seeded into 96-well tissue culture plates at a density of 12,500 cells per well. At $\sim 70 \%$ confluency, media was changed to DMEM without serum and immediately treated with increasing concentrations of triclosan (in ethanol), triclosan dissolved in a CPC solution with a final concentration of CPC $(0.024 \mu \mathrm{g} / \mathrm{ml})$, or CPC alone (in water). " The final concentration of ethanol was constant throughout all experiments. The final concentration of CPC used in these studies was provided by the manufac- turer. Treated HGF-1 cells were incubated for 24 to 72 hours. Following incubation, cytotoxicity was assessed** following the manufacturer's guidelines. In these experiments, the amount of reduced formazan product is directly proportional to the number of viable cells. Formazan accumulation was quantitated by absorbance at $490 \mathrm{~nm}$ by an enzyme-linked immunosorbent assay (ELISA) plate reader ${ }^{\dagger \dagger}$ and analyzed. ${ }^{\ddagger}$ The viability of cell cultures was normalized to $100 \%$ viability established in untreated control cultures at the time of indicated agent addition.

\section{$P G E_{2}$ Immunoassay}

HGF- 1 cells were grown to near confluency in 12-well dishes and pretreated for 1 hour with triclosan or triclosan plus CPC and were then challenged with either TNF $-\alpha(1 \mathrm{ng} / \mathrm{ml})$ or IL- $1 \beta(1 \mathrm{ng} / \mathrm{ml})$ for 18 to 24 hours. The amount of $\mathrm{PGE}_{2}$ released from HGF-1 cells into the cultured supernatant was measured using an enzyme immunoassay kit. $\S \S$ Absorbance was determined at $405 \mathrm{~nm}$ by an ELISA plate readellll and analyzed. 9\% Quantities of $\mathrm{PGE}_{2}$ were expressed in $\mathrm{pg} / \mathrm{ml}$ of cultured supernatant. Controls for these experiments included untreated cells to measure constitutive production of $\mathrm{PGE}_{2}$ as well as cells pretreated with triclosan or triclosan plus CPC only.

\section{Total RNA Isolation and Reverse Transcription-Polymerase Chain Reaction (RT-PCR) Analysis}

Total RNA from untreated and treated human gingival fibroblasts was isolated using reagent ${ }^{\# \#}$ as described previously. ${ }^{19,20}$ Total RNA integrity was assessed by gel electrophoresis under denaturing conditions. Five micrograms of total RNA was used for cDNA synthesis with oligo(dT) $12-18$ primer and $\mathrm{RnaseH}^{-* * *}$ in RT reactions. Resulting cDNA was used as a template in $\mathrm{PCR}$ reactions. Two microliters of $\mathrm{RT}$ product was used as a template for PCR amplification of COX-1, COX-2, and $\beta$-actin cDNA sequences. The following primer sets in these experiments were derived from human sequence data: COX-1 (GenBank accession number U63846, 303 base pairs (bp): forward, 5' -TGC CCA GCT CCT GGC CCG CCG CTT-3'; reverse, 5'-GTG CAT CAA CAC AGG CGC CTC TTC-3'), COX-2 (M90100, 305 bp: forward, 5'-TTC AAA TGA GAT TGT GGG AAA ATT GCT-3'; reverse, 5' -AGA TCA

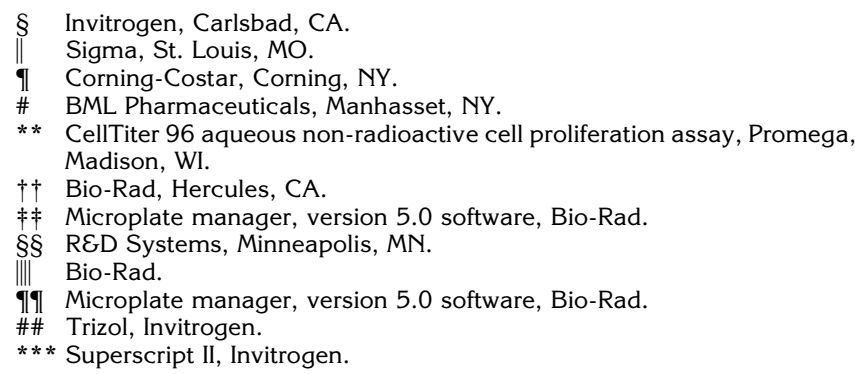


TCT CTG CCT GAG TAT CTT-3'), and $\beta$-actin (NT011520, 300 bp: forward, 5'-AGCGGGAAATCGTGCGTG-3'; reverse, 5' -CAGGGTACATGGTGGTG-CC-3'). The PCR amplification conditions employed standard $94^{\circ} \mathrm{C}$ denaturation for 1 minute, annealing at $55^{\circ} \mathrm{C}$ for 2 minutes, and extension at $72^{\circ} \mathrm{C}$ for 2 minutes for 30 cycles with a final extension at $72^{\circ} \mathrm{C}$ for 10 minutes. Semiquantitative comparison with $\beta$-actin, a housekeeping gene, was made to assess changes in gene expression due to experimental treatments. A total of $10 \mu \mathrm{l}$ PCR products were quantitated ${ }^{\dagger \dagger \uparrow \uparrow}{ }^{\dagger}$ following electrophoresis and ethidium bromide staining. Experiments were repeated three times and representative data are presented.

\section{Western Blot Analysis}

HGF-1 cells were exposed to triclosan in ethanol vehicle or CPC containing vehicle for $\sim 45$ minutes, then stimulated with IL-1 $\beta(1 \mathrm{ng} / \mathrm{ml})$ or TNF- $\alpha(1 \mathrm{ng} / \mathrm{ml})$ for 10 minutes. Cells were rinsed with ice-cold sodium dodecyl sulfate polyacrylamide gel electrophoresis (SDS-PAGE) buffer.§§§ Protein concentrations were measured by Bradford's method.|l||l| Ten micrograms of each sample was electrophoresed on $10 \%$ denatured SDS-PAGE gels and electrotransferred to nitrocellulose membranes. "Tा Antibodies against phosphorylated forms of p38 mitogen-activated protein kinase (MAPK) and the nuclear factor-kappa $B$ $(\mathrm{NF}-\kappa \mathrm{B})$ p65 subunit ${ }^{\# \# \#}$ were used as primary antibodies in these studies. Antibodies against $\mathrm{GAPDH}^{* * * *}$ were used to compare total protein loaded onto the gel. Primary antibodies were detected using horseradish peroxidase (HRP)-conjugated secondary antibodies and chemiluminescence detection. ${ }^{\dagger \dagger \dagger}$

\section{RESULTS}

\section{Gingival Fibroblast Cytotoxicity to \\ Triclosan and Cetylpyridinium Chloride}

To gain pharmacological insight into the role of triclosan and CPC on prostaglandin inhibition, cell cytotoxicity assays were performed to determine noncytotoxic concentrations for subsequent studies. As shown in Figure 1, 60\% to $70 \%$ confluent cultures of HGF-1 cells were incubated with increasing concentrations of triclosan, triclosan and CPC, or CPC alone. In all experiments, HGF-1 cells were grown in the presence of $0 \%$ fetal calf serum (FCS) to ascertain the cytotoxicity in the absence of FCS. In all experiments ( $N=3$ measured in triplicate), triclosan and triclosan and CPC reagents were cytotoxic at concentrations exceeding $1.0 \mu \mathrm{g} / \mathrm{ml}$ for 72 -hour time periods $(P<0.01)$. For CPC alone, concentrations of $1 \mu \mathrm{g} / \mathrm{ml}$ decreased cell viability for 24- and 72-hour time points $(P<0.05)$ with no difference between time points. Similar results were obtained with reagents in $2 \% \mathrm{FCS}$ (data not shown). Thus, at concentrations $<1.0 \mu \mathrm{g} / \mathrm{ml}$, there were no significant cytotoxicity effects of cetylpyridinium chloride. These preliminary experiments established the pharmacological range of triclosan and triclosan and CPC to be used in all subsequent experiments. In the $\mathrm{PGE}_{2}$ immunoassays, as well as the RT-PCR analysis, triclosan was used in the 0.01 to $1.0 \mu \mathrm{g} / \mathrm{ml}$ range for time periods that did not exceed 24 hours. In addition, CPC was used at a final concentration of $0.024 \mu \mathrm{g} / \mathrm{ml}$ as determined by the manufacturer who was developing a mouthrinse product that contained triclosan and CPC, which never had measurable cytotoxic effects at 72 hours in culture. This time point was chosen to avoid confusion in data interpretation with cytotoxic levels of agents and time frames where these effects were experimentally observed.

\section{Triclosan and CPC Inhibition of $P G E_{2}$}

We performed immunoassays on cultured supernatants to determine if CPC had an additive effect on triclosan-mediated repression of cytokine-induced $\mathrm{PGE}_{2}$ production in gingival fibroblasts. The amounts of $\mathrm{PGE}_{2}$ were determined by a competitive immunoassay for $\mathrm{PGE}_{2}$ following treatment with triclosan or triclosan and CPC (at $0.024 \mu \mathrm{g} / \mathrm{ml}$ ) and subsequent stimulation with IL- $1 \beta$ or TNF- $\alpha$ for 18 hours. CPC in vehicle was held constant in all immunoassays. As shown in Figure 2, we observed a dose dependent inhibition of $\mathrm{PGE}_{2}$ secretion after TNF- $\alpha$ (Fig. 2A) or IL-1 $\beta$ (Fig. 2B) stimulation by both triclosan and triclosan and cetylpyridinium chloride. Unstimulated cultures had non-detectable levels of $\mathrm{PGE}_{2}$ (data not shown). At concentrations of $1.0 \mu \mathrm{g} / \mathrm{ml}$ triclosan, in both ethanol vehicle and CPC, significant inhibition of TNF- $\alpha$-induced $\mathrm{PGE}_{2}$ was observed $(P<0.05)$. However, no differences between vehicles were observed at the same triclosan concentrations in TNF- $\alpha$ stimulated cultures. In contrast, significant differences between vehicles were observed in IL- $1 \beta$ stimulated cells. Here, a dose dependent inhibition of IL-1 $\beta$-induced $\mathrm{PGE}_{2}$ production was observed with triclosan in either ethanol or CPC-containing vehicle reaching significance at $1 \mu \mathrm{g} / \mathrm{ml}(P<0.01)$. Moreover, a significant decrease in $\mathrm{PGE}_{2}$ secretion was observed at both $100 \mathrm{ng} / \mathrm{ml}$ and $1.0 \mu \mathrm{g} / \mathrm{ml}$ of triclosan in CPC vehicle in comparison to some triclosan concentrations in ethanol vehicle $(P=0.02)$. In these studies, we observed an average increase in $\mathrm{PGE}_{2}$ inhibition in the presence of CPC of $13 \%$ to $19 \%$ at $1.0 \mu \mathrm{g} / \mathrm{ml}$

\footnotetext{
$\dagger \dagger$ Phosphoimager system, Bio-Rad.

邦 Molecular Analyst, version 1.5 software, Bio-Rad.

$\S \S \S$ Bio-Rad.

IIIII Bio-Rad.

ขी

\#\#\# Cell Signaling Technologies, Beverly, MA

$* * * *$ Chemicon, Temecula, CA.

$\dagger \dagger \dagger \dagger$ LumniGlo, Cell Signaling Technologies.
} 

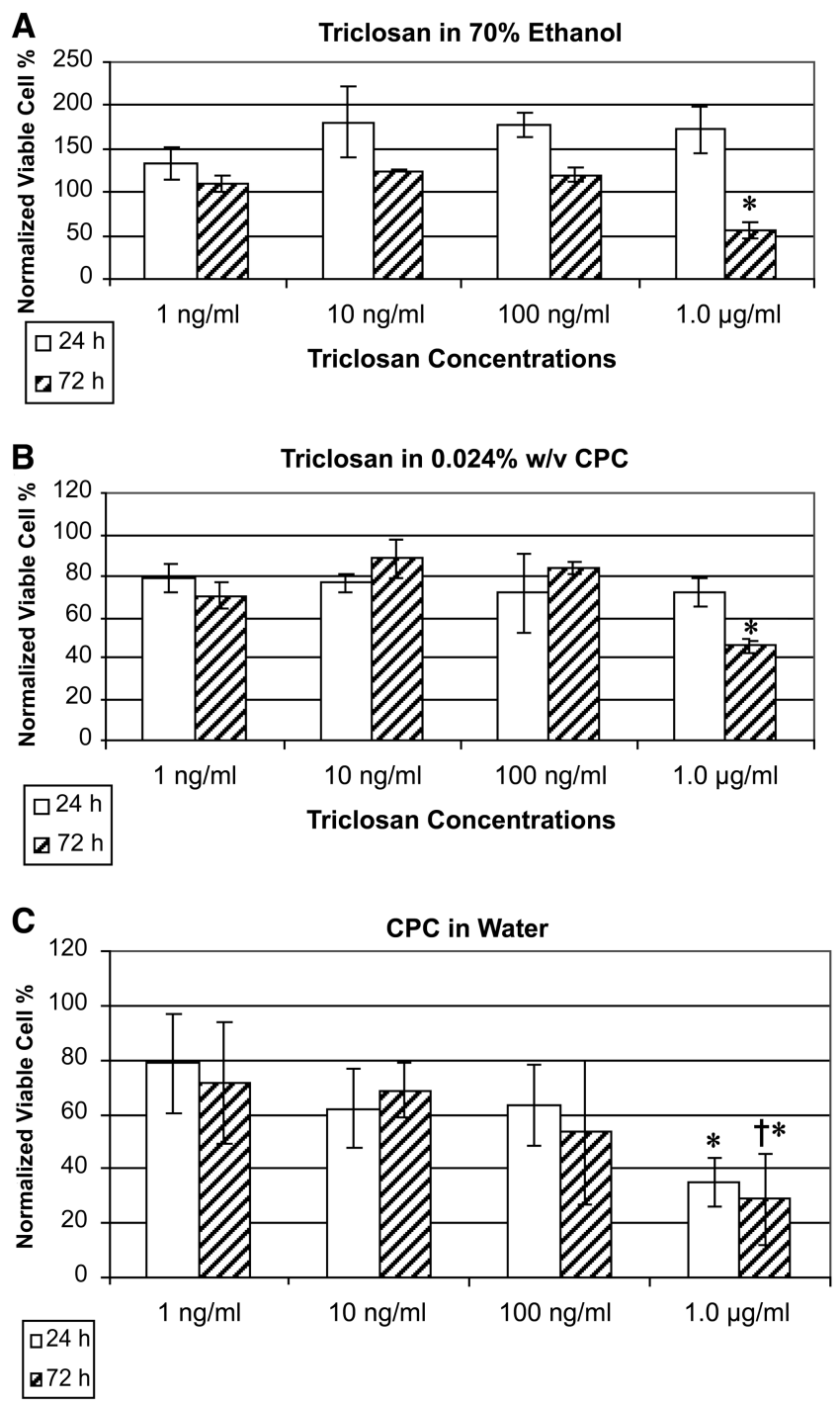

Figure I.

Methyl tetrazolium salt (MTS) assay for HGF-I cell viability with triclosan in ethanol vehicle (A), triclosan with CPC $(0.0024 \mu \mathrm{g} / \mathrm{ml})$ (B), or CPC alone (C) at 24- and 72-hour time points is indicated. All experiments were conducted in duplicate and measured in triplicate with methylthiazoletetrazolium (MTT) assay reagents. Significant differences in cytotoxicity between treated and untreated cells are indicated by an asterisk $(* P<0.01)$. ${ }^{\dagger}$ Significant difference between I $\mu \mathrm{g} / \mathrm{ml}$ treatment and either I- or $10-\mathrm{ng} / \mathrm{m} /$ treated cells.

and $100 \mathrm{ng} / \mathrm{ml}$, respectively, when IL- $1 \beta$ was used to stimulate $\mathrm{PGE}_{2}$ production. In addition, $\mathrm{CPC}$ alone had significant inhibitory effect on TNF- $\alpha(P<0.05)$ at all concentrations tested, but only at $1.0 \mu \mathrm{g} / \mathrm{ml}$ $(P<0.01)$ did CPC significantly affect IL- $1 \beta$ stimulated $\mathrm{PGE}_{2}$ production in gingival fibroblasts (Fig. 3). However, a dose dependent inhibition was not observed in either cytokine stimulated culture.

\section{Selective Inhibition of COX-2 Gene Expression} To determine the molecular nature underlying the observed inhibitory events of triclosan $\pm \mathrm{CPC}$ on $\mathrm{PGE}_{2}$

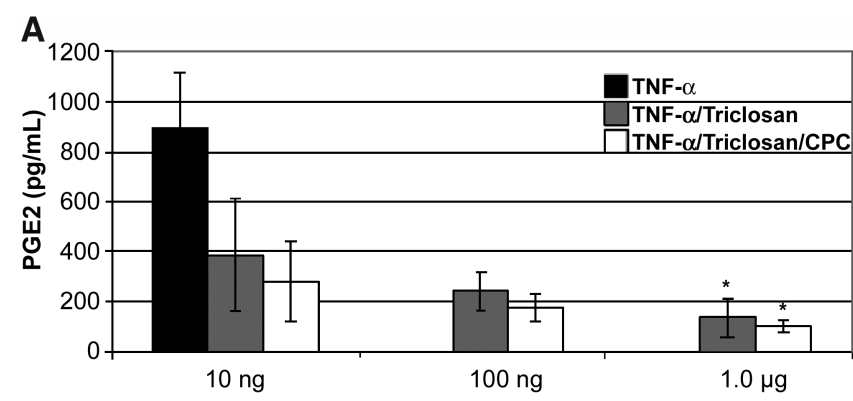

Triclosan Concentration

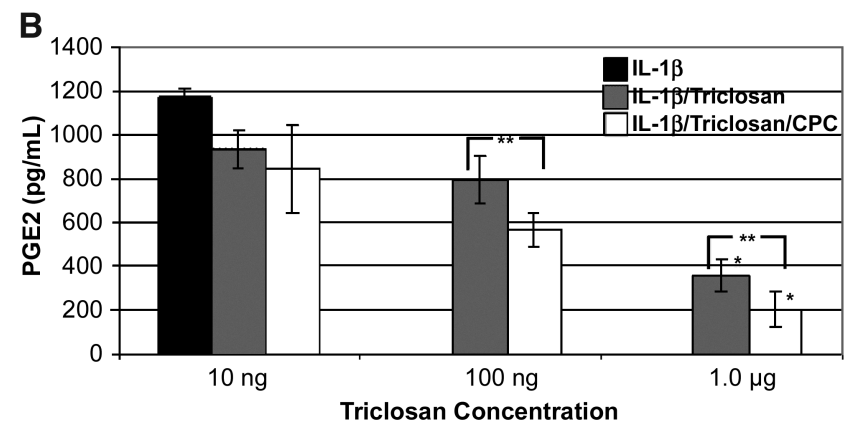

Figure 2.

Dose-dependent inhibition of $P G E_{2}$ in $H G F-I$ cells with triclosan and triclosan and CPC when stimulated for 18 hours with I $\mathrm{ng} / \mathrm{ml}$ of either TNF- $\alpha$ (A) or IL- I $\beta$ (B). PGE 2 was measured by ELISA assays and expressed in $\mathrm{pg} / \mathrm{ml}$. Significant differences from cytokine stimulated only are indicated with an asterisk (*) and were observed between triclosan and triclosan and CPC at concentrations of 0.1 and $1.0 \mu \mathrm{g} / \mathrm{ml}(\mathrm{P}<0.0 \mathrm{I})$ for either TNF- $\alpha$ (A) or IL- I $\beta$ (B). Significant differences between triclosan in ethanol and triclosan in CPC were observed at 0.1 and $1.0 \mu \mathrm{g} / \mathrm{ml}$ in IL-I $\beta$ stimulated cells $(P=0.021)$. These data represent four independent experiments measured in duplicate.

production, we determined the expression of COX-1, COX-2, and the housekeeping gene $\beta$-actin in HGF1 cells. Using semiquantitative RT-PCR, Figure 4 shows that COX-1 was constitutively expressed in these cells under all conditions, but COX-2 was highly regulated. COX-2 gene expression was increased approximately six-fold with TNF- $\alpha$ (Fig. 4A), but TNF- $\alpha$ induced COX-2 expression was significantly inhibited by triclosan (1.7-fold reduction) and to a slightly greater extent with triclosan and cetylpyridinium chloride (2.6-fold reduction). In addition, the specific COX-2 inhibitor NS-398 showed similar COX-2 inhibitory activity compared to triclosan and triclosan and cetylpyridinium chloride (data not shown).

When cells were stimulated with IL-1 $\beta$ after pretreatment with triclosan or triclosan and cetylpyridinium chloride, we observed repression of IL-1 $\beta$ induced COX-2 expression. As shown in Figure 4B, we again observed repression of COX-2 gene expression in the presence of triclosan (2.6-fold reduction) and slightly more repression with triclosan and cetylpyridinium chloride (2.9-fold reduction). In addition, 

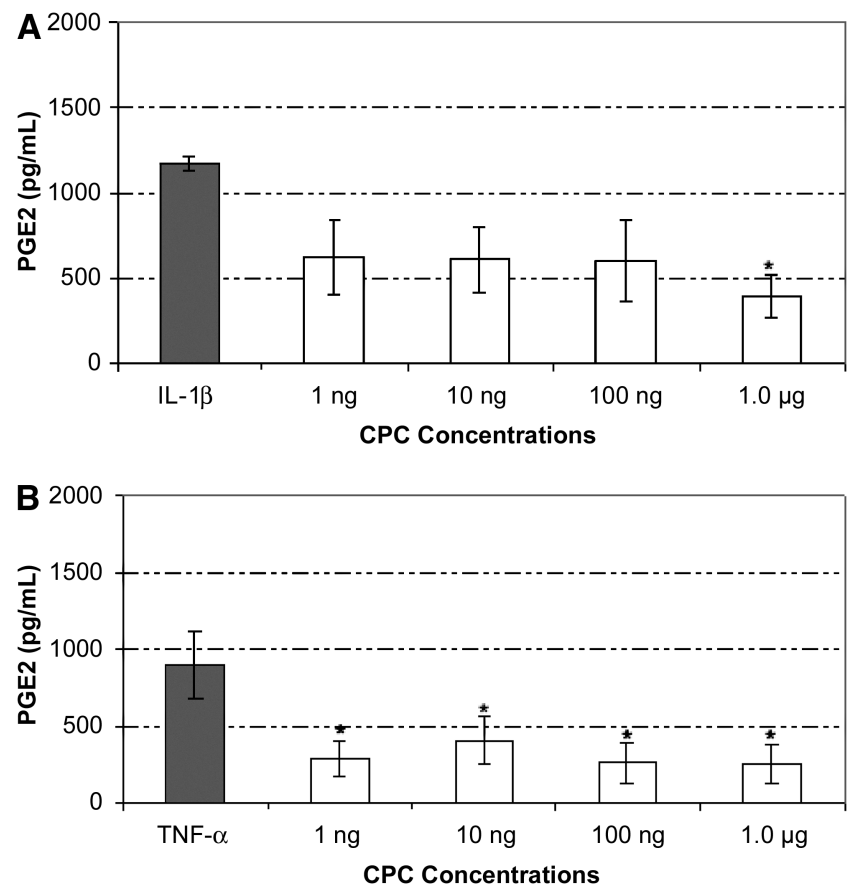

Figure 3.

Effect of CPC on cytokine-induced $P G E_{2}$ production in HGF cells.

$P G E_{2}$ was measured from cultured supernatants following 18-hour treatment with CPC and cytokine stimulation by ELISA assays.

Significant differences, indicated with an asterisk (*), were observed at $1.0 \mu \mathrm{g} / \mathrm{ml}$ in IL- $/ \beta$ (A) $(\mathrm{P}<0.0$ I) and all of TNF- $\alpha$ (B) $(\mathrm{P}<0.05)$ treated cells compared to stimulated controls. These data represent two independent experiments measured in duplicate.

no significant changes in COX-1 gene levels were observed by semiquantitative RT-PCR.

\section{Signaling Intermediates Inhibited by Triclosan and CPC}

To understand the selective inhibitory effects of triclosan and CPC on COX-2 gene expression in gingival fibroblasts, we sought to evaluate the effect of triclosan and CPC on key signal transduction intermediates that contribute to cytokine stimulated COX-2 gene expression. As shown in Figure 5, following a shortterm stimulation with IL-1 $\beta$ and TNF- $\alpha$, both $\mathrm{p} 38$ MAPK and NF- $\mathrm{kB}$ signaling pathways are activated as indicated by increased phosphorylated levels of these signaling intermediates. In the case of TNF- $\alpha$, we observed less NF-kB induction, most likely due to suboptimal concentrations of this cytokine. However, for consistency throughout these studies, the same experimental concentrations of TNF- $\alpha$ were used for PGE $\mathrm{PLLISA}_{2}$ and COX-2 gene expression experiments in which an increase in protein and gene expression were observed, respectively. Most intriguing in these studies, triclosan in CPC vehicle inhibited NF- $\mathrm{kB}$ p65 phosphorylation. In triclosan-only or $\mathrm{CPC}$-only pretreated cells, this effect was not ob-
A

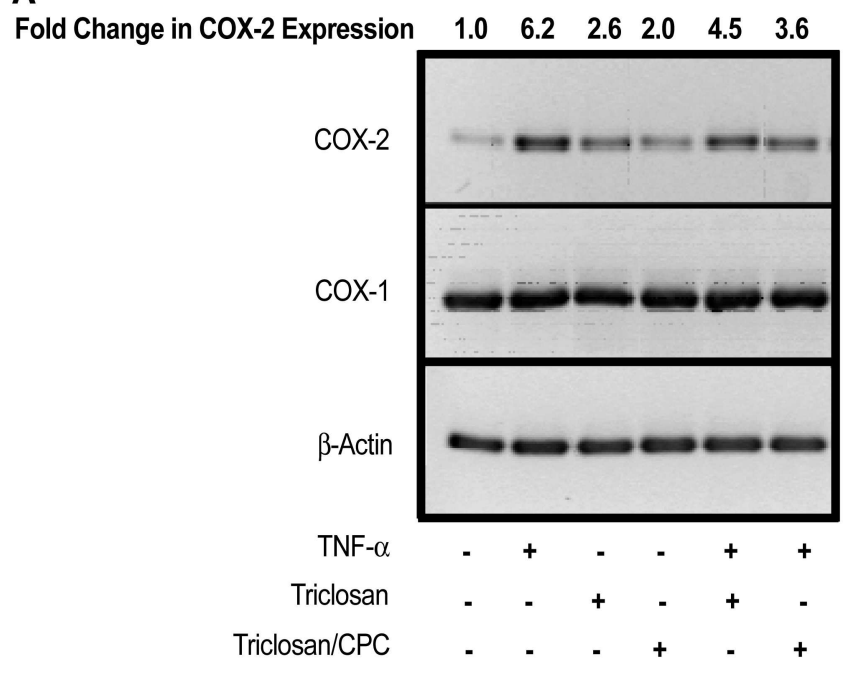

B

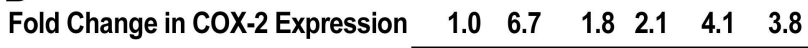

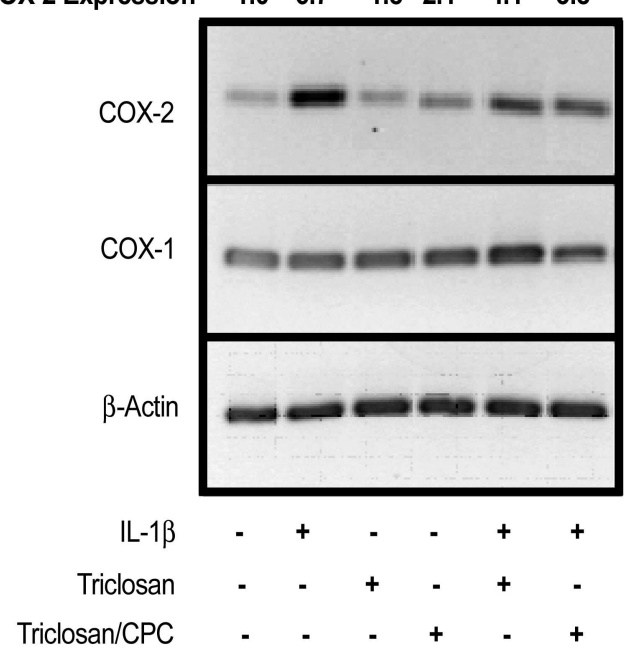

Figure 4.

RT-PCR analysis of COX-I and COX-2 mRNA expression in HGF-I cells. Cells were incubated with (A) TNF- $\alpha$ (I ng/ml) or (B) $\mid L-/ \beta$ $(\mathrm{I} g / \mathrm{ml})$ for 18 hours following pretreatment with triclosan or triclosan and CPC. RT-PCR specific products for COX-I, COX-2, and $\beta$-actin were analyzed by agarose gel electrophoresis and digitized. Fold change in COX-2 gene expression is shown as fold change relative to control (untreated) mRNA. The representative figure shown was repeated in three separate experiments with similar results.

served. This effect was not observed with p38 MAPK phosphorylated levels, indicating a specific pharmacological action of triclosan and CPC. GAPDH indicates that there were even quantities of total cell lysates blotted onto the membrane.

\section{DISCUSSION}

In these studies, we are able to demonstrate that CPC enhances the ability of triclosan to inhibit 


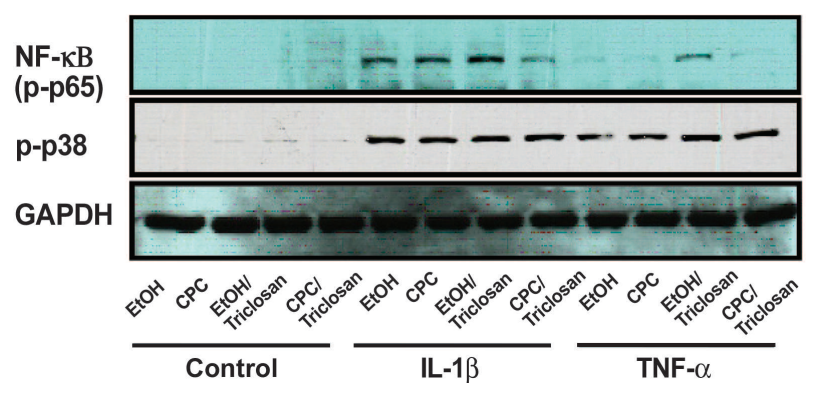

Figure 5.

Western blot analysis of NF-kB and p38 MAPK activation in HGF-I cells treated with triclosan or CPC. Cells were pretreated for 45 minutes with triclosan $(I \mu \mathrm{g} / \mathrm{ml})$ in $70 \%$ ethanol or triclosan $(\mathrm{l} \mu \mathrm{g} / \mathrm{ml})$ in a CPC-containing vehicle $(24 \mathrm{ng} / \mathrm{ml})$. Cells were stimulated with $|\mathrm{L}-| \mid \beta(\mid \mathrm{ng} / \mathrm{ml})$ or TNF- $\alpha(\mid \mathrm{ng} / \mathrm{ml})$ for 10 minutes. Whole cell lysates were used for Western blot analysis. Antibodies against phosphorylated $p 38$ ( $p$-p38) MAPK or NF-kB (p-p65) were used to assess the effects of triclosan $\pm C P C$ on key signaling intermediates known to be involved in COX-2 gene expression. GAPDH probe was used to indicate even loading of protein. Results are representative of two independent experiments where similar results were obtained.

proinflammatory cytokine stimulation of $\mathrm{PGE}_{2}$. Both TNF $-\alpha$ and IL- $1 \beta$ were shown to be potent inducers of $\mathrm{PGE}_{2}$ production in human gingival fibroblasts. These results are consistent with previous investigators who showed triclosan could inhibit fibroblast-derived $\mathrm{PGE}_{2}$ production. ${ }^{16}$ Also in agreement with other investigators, we have demonstrated the ability of triclosan to inhibit prostaglandin biosynthesis when challenged by either IL- $1 \beta$ or TNF- $\alpha .{ }^{15}$

Cytotoxicity studies with triclosan indicated that concentrations of $1 \mu \mathrm{g} / \mathrm{ml}$ for more than 24 hours resulted in significant loss of cell viability. Furthermore, CPC alone was cytotoxic to gingival fibroblasts at concentrations of $1.0 \mu \mathrm{g} / \mathrm{ml}$ at 24- and 72-hour time periods. The present study contrasts with previous studies that observed cytotoxicity at much higher concentrations of triclosan with gingival fibroblasts. $^{21,22}$ These observed differences may be due to the cell line used as they were different between studies.

In pharmacologically relevant ranges of agents tested in this study, we have shown that both triclosan and triclosan and CPC could dose dependently inhibit $\mathrm{PGE}_{2}$ biosynthesis (Figs. 2A and 2B). Although statistical differences between triclosan and triclosan and CPC were observed at $100 \mathrm{ng} / \mathrm{ml}$ and $1.0 \mu \mathrm{g} / \mathrm{ml}$ only in IL-1 $\beta$ stimulated cultures, a general trend toward greater $\mathrm{PGE}_{2}$ inhibition in $\mathrm{CPC}$ containing cultures was consistently observed throughout these experiments. Importantly, these data support the fact that triclosan can function as a potent anti-inflammatory agent. At the highest concentrations tested in these studies, we observed an $83 \%$ to $93 \%$ reduction in IL-
$1 \beta$ and TNF- $\alpha$-induced $\mathrm{PGE}_{2}$ biosynthesis with triclosan in a CPC-containing vehicle. These present results suggest that $C P C$ may enhance uptake of triclosan at lower concentrations where differences between treatment groups could be observed relative to prostaglandin inhibition. Other recent studies have suggested that cationic compounds, e.g., CPC, can act as an absorption enhancer. ${ }^{18}$ This may explain our findings that CPC enhanced the ability of triclosan to inhibit cytokine induced prostaglandin production. In addition, CPC by itself also affected cytokineinduced $\mathrm{PGE}_{2}$ production in HGF cells (Fig. 3). Although there appears to be a dose independent effect of CPC or cytokine-induced $\mathrm{PGE}_{2}$ production, the effects observed seem to be significant in TNF stimulated cultures at all concentrations tested. Further titration is required to substantiate the concentration where no $\mathrm{PGE}_{2}$ inhibition is observed. Collectively, these data suggest that the CPC functions to enhance prostaglandin inhibition in the presence of triclosan. Thus, at low concentrations of cetylpyridinium chloride, this agent may facilitate the effects of other agents or have anti-inflammatory properties itself, providing a novel combination of oral pharmacological delivery of chemotherapeutic and anti-inflammatory agents.

To explore the possible molecular events that were affected by triclosan and triclosan plus cetylpyridinium chloride, we evaluated the steady state gene expression of COX-1 and COX-2. Since COX-2 gene expression is one of the major regulators of prostaglandin production, we wanted to determine if triclosan plus CPC could repress COX-2 gene expression more than triclosan alone. As shown in Figure 4, both triclosan and triclosan in a CPC vehicle were able to reduce TNF- $\alpha$ or IL-1 $\beta$-induced COX- 2 gene expression. The extent of inhibition was consistently more with triclosan plus CPC than triclosan alone. Also, neither agent affected COX-1 gene expression. Because RT-PCR is a semiquantitative means of measuring gene expression, we cannot state for sure if COX-2 gene expression was repressed with triclosan plus CPC statistically more than with triclosan alone. However, theses changes were consistent throughout all of these experiments indicating that COX-2 gene expression is reduced with triclosan plus CPC more than triclosan alone.

The COX-2 gene is highly regulated in all tissues and several key intracellular pathways have been implicated in its regulation. Several intracellular signaling proteins have been implicated in COX-2 gene regulation, including protein kinase $\mathrm{C}(\mathrm{PKC}),{ }^{23} \mathrm{p} 38$ MAPK, ${ }^{24,25}$ and NF-кB. ${ }^{26}$ Triclosan with CPC seems to specifically inhibit NF-кB p65 phosphorylation (Fig. 5). No effect on p38 phosphorylation was observed. NF- $\kappa \mathrm{B}$ has been well established and a potent 
transcriptional activator of inducible COX-2 gene expression in response to IL-1 $1 \beta$ or TNF- $\alpha .{ }^{27-29}$ The COX-2 gene promoter contains NF-кB sites -223 / -214 and has been shown to be important along with other transcription factors in COX-2 transcriptional activation. ${ }^{30}$ In addition, both TNF- $\alpha$ and IL- $1 \beta$ have been shown to mediate prostaglandin production partly at the level of COX-2 and at the level of PLA 2 in a PKC-dependent manner in gingival fibroblasts. ${ }^{23}$ To our knowledge, this is the first study that has attempted to discern if signaling cascades may be affected directly by triclosan/CPC. Future studies will address the molecular nature of triclosan/CPC repression of NF- $\mathrm{kB}$ activity.

It is possible that gingival fibroblasts along with resident macrophages and other immune cells contribute to the $\mathrm{PGE}_{2}$ levels that are increased in gingival crevicular fluid in periodontitis patients. ${ }^{31}$ Our findings that triclosan and CPC enhance the inhibitory effect of triclosan upon proinflammatory cytokine induced prostaglandin production offer a potential novel combination for the treatment of gingival inflammation. Levels of CPC that did not approach cytotoxic levels may provide enhanced control of gingival inflammation mediated by $\mathrm{PGE}_{2}$. Furthermore, control of $\mathrm{PGE}_{2}$ in gingival fibroblasts may provide a novel basis for inflammatory management of prevention of periodontal disease pathogenesis.

\section{ACKNOWLEDGMENTS}

These studies were supported by BML Pharmaceuticals, Manhasset, New York and Endo Pharmaceuticals, Chadds Ford, Pennsylvania.

\section{REFERENCES}

1. Birkedal-Hansen H. Role of matrix metalloproteinases in human periodontal diseases. J Periodontol 1993; 64:474-484.

2. Miossec P. Cytokines in rheumatoid arthritis: Is it all TNF-alpha? Cell Mol Biol (Noisy-le-grand) 2001; 47:675-678.

3. Greenfield EM, Bi Y, Miyauchi A. Regulation of osteoclast activity. Life Sci 1999;65:1087-1102.

4. Gravallese EM, Galson DL, Goldring SR, Auron PE. The role of TNF-receptor family members and other TRAF-dependent receptors in bone resorption. Arthritis Res 2001;3:6-12.

5. Wilson M. Biological activities of lipopolysaccharides from oral bacteria and their relevance to the pathogenesis of chronic periodontitis. Sci Prog 1995;78: 19-34.

6. Koka S, Reinhardt RA. Periodontal pathogen-related stimulation indicates unique phenotype of primary cultured human fibroblasts from gingiva and periodontal ligament: Implications for oral health disease. J Prosthet Dent 1997;77:191-196.

7. Sjostrom S, Hanstrom L, Lerner UH. The bone resorbing activity released by gingival fibroblasts isolated from patients with periodontitis is independent of interleukin-1. J Periodontal Res 2000;35:74-84.
8. Offenbacher S, Collins JG, Heasman PA. Diagnostic potential of host response mediators. Adv Dent Res 1993; 7:175-181.

9. Offenbacher S. Periodontal diseases: Pathogenesis. Ann Periodontol 1996;1:821-878.

10. Lasa M, Brook M, Saklatvala J, Clark AR. Dexamethasone destabilizes cyclooxygenase 2 mRNA by inhibiting mitogen-activated protein kinase p38. Mol Cell Biol 2001;21:771-780.

11. Hu D, Zhang J, Wan H, Zhang Y, Volpe AR, Petrone ME. Hua Xi Kou Qiang Yi Xue Za Zhi 1997;15:333335.

12. Lindhe J, Rosling B, Socransky SS, Volpe AR. The effect of a triclosan-containing dentifrice on established plaque and gingivitis. J Clin Periodontol 1993; 20:327-334

13. Barkvoll P, Rolla G. Triclosan protects the skin against dermatitis caused by sodium lauryl sulphate exposure. $J$ Clin Periodontol 1994;21:717-719.

14. Kjaerheim V, Barkvoll P, Waaler SM, Rolla G. Triclosan inhibits histamine-induced inflammation in human skin. J Clin Periodontol 1995;22:423-426.

15. Modeer T, Bengtsson A, Rolla G. Triclosan reduces prostaglandin biosynthesis in human gingival fibroblasts challenged with interleukin-1 in vitro. J Clin Periodontol 1996;23:927-933.

16. Gaffar A, Scherl D, Afflitto J, Coleman EJ. The effect of triclosan on mediators of gingival inflammation. $J$ Clin Periodontol 1995;22:480-484.

17. Nafee NA, Boraie MA, Ismail FA, Mortada LM. Design and characterization of mucoadhesive buccal patches containing cetylpyridinium chloride. Acta Pharm 2003; 53:199-212.

18. Natsume H, Iwata S, Ohtake K, et al. Screening of cationic compounds as an absorption enhancer for nasal drug delivery. Int J Pharm 1999;185:1-12.

19. Bradford PG, Maglich JM, Ponticelli AS, Kirkwood KL. The effect of bone morphogenetic protein-7 on the expression of type I inositol 1,4,5-trisphosphate receptor in G-292 osteosarcoma cells and primary osteoblast cultures. Arch Oral Biol 2000;45:159-166.

20. Kirkwood KL, Golub LM, Bradford PG. Non-antimicrobial and antimicrobial tetracyclines inhibit IL-6 expression in murine osteoblasts. Ann N Y Acad Sci 1999; 878:667-670.

21. Zuckerbraun HL, Babich H, May R, Sinensky MC. Triclosan: Cytotoxicity, mode of action, and induction of apoptosis in human gingival cells in vitro. Eur J Oral Sci 1998;106:628-636.

22. Babich H, Babich JP. Sodium lauryl sulfate and triclosan: In vitro cytotoxicity studies with gingival cells. Toxicol Lett 1997;91:189-196.

23. Yucel-Lindberg T, Ahola H, Carlstedt-Duke J, Modeer $\mathrm{T}$. Involvement of tyrosine kinases on cyclooxygenase expression and prostaglandin $\mathrm{E}_{2}$ production in human gingival fibroblasts stimulated with interleukin-1beta and epidermal growth factor. Biochem Biophys Res Commun 1999;257:528-532.

24. Molina-Holgado E, Ortiz S, Molina-Holgado F, Guaza C. Induction of COX-2 and PGE(2) biosynthesis by IL-1beta is mediated by PKC and mitogen-activated protein kinases in murine astrocytes. $\mathrm{Br} J$ Pharmacol 2000;131:152-159.

25. Ridley SH, Dean JL, Sarsfield SJ, Brook M, Clark AR, Saklatvala J. A p38 MAP kinase inhibitor regulates stability of interleukin-1-induced cyclooxygenase-2 mRNA. FEBS Lett 1998;439:75-80. 
26. Bauer MK, Lieb K, Schulze-Osthoff K, et al. Expression and regulation of cyclooxygenase-2 in rat microglia. Eur J Biochem 1997;243:726-731.

27. Rothwarf DM, Karin M. The NF-kappa B activation pathway: A paradigm in information transfer from membrane to nucleus. Sci STKE 1999;1999:RE1.

28. Nakao S, Ogata Y, Shimizu-Sasaki E, Yamazaki M, Furuyama S, Sugiya H. Activation of NFkappaB is necessary for IL-1beta-induced cyclooxygenase-2 (COX-2) expression in human gingival fibroblasts. Mol Cell Biochem 2000;209:113-118.

29. Nakao S, Ogtata Y, Shimizu E, Yamazaki M, Furuyama S, Sugiya H. Tumor necrosis factor alpha (TNF-alpha)-induced prostaglandin $\mathrm{E}_{2}$ release is mediated by the activation of cyclooxygenase-2 (COX-2) transcription via NFkappaB in human gingival fibroblasts. Mol Cell Biochem 2002;238:11-18.
30. Mestre JR, Mackrell PJ, Rivadeneira DE, Stapleton PP, Tanabe T, Daly JM. Redundancy in the signaling pathways and promoter elements regulating cyclooxygenase-2 gene expression in endotoxin-treated macrophage/monocytic cells. J Biol Chem 2001;276: 3977-3982.

31. Offenbacher S, Heasman PA, Collins JG. Modulation of host $\mathrm{PGE}_{2}$ secretion as a determinant of periodontal disease expression. J Periodontol 1993;64:432-444.

Correspondence: Dr. Keith L. Kirkwood, Department of Periodontics and Oral Medicine, University of Michigan, 1011 N. University Ave., Ann Arbor, MI 48109-1078. Fax: 734/763-5503; e-mail: klkirk@umich.edu.

Accepted for publication March 7, 2005. 